\title{
Digitalization of the housing and communal services: development prospects
}

\author{
Ekaterina Dmitrieva* \\ Moscow State University of Civil Engineering, Yaroslavskoe shosse, 26, Moscow, 129337, Russia
}

\begin{abstract}
The subject of the research is to study the impact of modern digital technologies on the organization and management of public utilities within the framework of the concept of "smart HCS", which ensures optimization of municipal budgets, reducing the costs of homeowners for the maintenance of real estate, and, as a result, improving the quality of life of citizens. The purpose of the study is to identify promising areas of digitalization of the housing and communal services sector (hereinafter referred to as HCS), creating comfortable and safe living conditions for citizens using smart technologies adapted to the "smart city" concept. In the course of the study, the methods of scientific analysis were used, including methods of analogies for generalization and comparative analysis of the digitalization of such areas as the "smart" housing sector and the "smart" utility sector. The result of the study is to highlight the most promising areas of digital transformation of the public utilities sector and the positive effect that can be obtained for each participant in this business process. As a conclusion, it should be noted that the active implementation of the concept of "smart HCS" will help in solving such problems as increasing the readiness of management companies and resource supplying organizations to use digital technologies for high-quality provision of public services to the population, intensifying work on the formation of a unified information environment for control and supervision in the field of HCS through the further development of SIS HCS, etc.
\end{abstract}

\section{Introduction}

In the context of new economic realities, the prospects for the development and implementation of digital technologies in everyday life form the basis of the "Smart City" project proposed by the Ministry of Construction, Housing and Utilities of the Russian Federation [1]. In another document - Guidelines for the preparation of the regional project "Smart City" programs, the development of digital economy of the Russian Federation, said that "the Smart City project is aimed at increasing the competitiveness of Russian cities, creating an effective urban management system, creating safe and comfortable living conditions for citizens. There are five key principles that a modern smart city must comply with:

\footnotetext{
* Corresponding author: k_dim73@mail.ru
} 
1) focus on human;

2) manufacturability of urban infrastructure;

3) improving the quality of urban resource management;

4) comfortable and safe environment;

5) emphasis on economic efficiency, including the service component of the urban environment" [2].

The implementation of these principles is carried out through the widespread implementation of advanced digital solutions in urban and municipal infrastructure, contributing to the provision of high living standards for citizens.

The aim of the study is to identify promising areas of digitalization of the housing and utilities sector, creating comfortable and safe living conditions for citizens using smart technologies adapted to the concept of a smart city.

A large number of "smart" projects are developed and implemented annually, including those affecting the digitalization of the utilities sector, whose IT solutions ensure optimization of municipal budgets, reduce the expenses of homeowners for maintaining real estate, and, as a result, improve the quality of life of citizens. In addition, intelligent solutions in the management of housing and communal services enable residents to actively participate in the formation and management of the urban environment, round-the-clock access to city services from any device, as well as the growth of energy efficiency and environmental friendliness of the communal complex.

World practice shows the successful implementation and use of digital technologies in the construction of smart neighborhoods and settlements, taking into account the needs of residents, funding opportunities, long-term goals for the development of a smart urban environment. Thus, similar projects are currently being implemented all over the world: in Europe, the USA, Brazil, Israel, the United Arab Emirates, China, Singapore, as well as in Russia and neighboring countries [3].

The bank of technologies and solutions in the field of urban economy presents 349 projects in the field of smart cities. Ninety four projects are related to the digitalization of HCS - these are smart meters transmitting readings in a remote mode, resource consumption control systems, and solutions that optimize the work of the emergency dispatch service [4].

In order for the digital transformation of the housing and utilities sector to be carried out more intensively, in 2017, the state approved the program "Digital Economy of the Russian Federation" [5], which sets out the requirements for transparency and efficiency of work on the maintenance of utilities.

Now the main problem of the active introduction and use of digital technologies in the HCS sector is that individual business processes have not yet been fully digitized and integrated with each other. In this regard, there is an objective need to create a unified information environment that allows all participants in the HCS complex to interact with each other. For example, there is a mobile application for citizens where you can contact the management company at any time and from anywhere. And for managing organizations, the system offers space for effective work: the system does not require installation (this is a cloud service), which means that you can get started quickly and without being tied to some location.

The digital transformation of HCS is a rather complex process that requires serious support, both from the state and from management companies and resource supplying organizations, for the implementation of digital technologies, which are becoming the very foundation that forms the digital ecosystem of smart cities. 


\section{Methods}

It is difficult to imagine the active development of smart cities without large-scale digitalization and automation of vital processes associated with the organization and management of various sectors of the urban infrastructure that provide comfortable living conditions in a modern city. A special place in the development of a smart city is occupied by the digital transformation of the management of engineering systems in order to increase their energy efficiency, environmental friendliness, energy and resource conservation, and create a comfortable microclimate for a modern urban environment.

Analyzing foreign and domestic experience in the implementation of the "smart city" concept, the main goal was to identify promising areas of digital transformation as one of the elements of the urban economy, which in the terminology of Russian experts is usually called "smart HCS".

According to the definition given on the IoT.ru portal, "smart HCS are part of the concept of a smart city, which is responsible for the automation of housing and communal services for timely receipt of meter readings, monitoring equipment operation, preventing emergencies, transparency of the operation of HCS objects, etc." [6]. In this context, housing and communal services are considered only from the position of the communal sector associated with the supply of communal resources to the end consumer and control of their consumption. In other Russian sources, "smart HCS" is considered from the point of view of a systematic approach to the use of digital technologies based on automatic collection and analysis of data coming from "smart" meters for the consumption of utility resources.

The purpose of the development of the concept of "smart HCS" is, first of all, to provide a comfortable and safe living environment, creating conditions for the rational use and saving of all types of resources, and most importantly, in a modern urban environment, the HCS sector should become effective and transparent. Individual components of "smart HCS" are already quite actively used in our life: these are modern metering devices, various sensors that monitor the state of objects and the environment in real time (photo and video recording, gas analyzers, temperature, pressure, motion sensors, illumination, etc.).

In this regard, an expert in the field of information technologies of the OTR company A.I. Kuleshov identified the following key tasks associated with the development of "smart HCS":

"1. Improving the efficiency of management processes - reducing losses, reducing indirect and overhead costs in tariffs, etc.

2. Reducing the volume of accounts receivable in the industry and the resulting additional financial burden on the business.

3. Ensuring transparency of the industry for public control and regulation.

4. Improving the quality of provided housing and communal services by creating elements of market competition in the industry and, as a result, reducing tariffs.

5. Formation of a database of complete, reliable and up-to-date data in the field of HCS on the state of the housing stock, on the volume and quality of provided services and energy consumption, on consumers of housing and communal services" [7].

At the moment, it is difficult to imagine the development of "smart HCS" without the active participation of residents in the management of their own housing in apartment buildings, without their support for the reorganization of various processes. Thus, the introduction and use of digital technologies and automated systems in everyday life should help and take into account the interests of various participants in relations in solving complex housing and communal issues. Using the material presented on the Youhouse.ru portal, Table 1 shows the interests of the digitalization of HCS processes of its main participants. 
Table 1. Interests of participants from digitalization of HCS processes.

\begin{tabular}{|c|c|c|}
\hline $\begin{array}{l}\text { Participants in the HCS } \\
\text { process }\end{array}$ & Role in the process & $\begin{array}{c}\text { Main interest from process } \\
\text { digitalization }\end{array}$ \\
\hline $\begin{array}{l}\text { 1. Service consumers } \\
\text { (residents and } \\
\text { organizations of the city) }\end{array}$ & $\begin{array}{l}\text { The population performs only } \\
\text { one task, in addition to the } \\
\text { main one - the consumption of } \\
\text { utility resources, their timely } \\
\text { payment. }\end{array}$ & $\begin{array}{l}\text { The population can significantly } \\
\text { benefit from the use of information } \\
\text { technology in HCS: } \\
\text { 1) the risk of errors when } \\
\text { transferring data from the IMD is } \\
\text { reduced; } \\
\text { 2) the costs of paying for consumed } \\
\text { utilities are reduced. }\end{array}$ \\
\hline $\begin{array}{l}\text { 2. Management company } \\
\text { (MC) and homeowners' } \\
\text { association (HOA) }\end{array}$ & $\begin{array}{l}\text { MC and HOA provide } \\
\text { residents with utilities and } \\
\text { manage apartment buildings. }\end{array}$ & $\begin{array}{l}\text { MC and HOA use smart solutions to } \\
\text { reduce the consumption of utility } \\
\text { resources in apartment buildings. }\end{array}$ \\
\hline $\begin{array}{l}\text { 3. Resource supplying } \\
\text { organization (RSO) }\end{array}$ & $\begin{array}{l}\text { RSOs are large monopolistic } \\
\text { organizations interested in } \\
\text { improving the energy } \\
\text { efficiency and environmental } \\
\text { friendliness of the resources } \\
\text { provided to the end consumer. }\end{array}$ & $\begin{array}{l}\text { As a benefit from the use of smart } \\
\text { technologies, one can note the } \\
\text { simplification of the procedure for } \\
\text { obtaining data on payment of utility } \\
\text { bills by the population, as well as } \\
\text { providing this information to the } \\
\text { population. This is done as quickly } \\
\text { and conveniently as possible. }\end{array}$ \\
\hline 4. Banking institutions & $\begin{array}{l}\text { Banking institutions accept } \\
\text { payments for utilities from the } \\
\text { population. }\end{array}$ & $\begin{array}{l}\text { For such institutions, it is important } \\
\text { not only to accept payment, but also } \\
\text { to attract more customers to their } \\
\text { company. The use of high- } \\
\text { performance and responsive } \\
\text { software can speed up the checkout } \\
\text { process and reduce customer's } \\
\text { waiting time in the queue. }\end{array}$ \\
\hline $\begin{array}{l}\text { 5. State (local } \\
\text { government) }\end{array}$ & $\begin{array}{l}\text { Local authorities ensure that } \\
\text { prices for utilities are } \\
\text { calculated as expediently as } \\
\text { possible, and that the quality of } \\
\text { services is in accordance with } \\
\text { the declared and required by } \\
\text { law. }\end{array}$ & $\begin{array}{l}\text { For constant control and supervision } \\
\text { over the activities of housing and } \\
\text { communal services, the authorities } \\
\text { need automated systems that allow } \\
\text { them to receive information from the } \\
\text { housing offices themselves and } \\
\text { HOAs through a single digital } \\
\text { platform. }\end{array}$ \\
\hline
\end{tabular}

Source: [8]

Next, let us turn to the results of an empirical study conducted by the Institute for Urban Economics Foundation as part of the work "Smart City - Smart HCS: review of trends in digitalization of urban economy". This study examines separately the digitalization of such areas as the "smart" housing sector and the "smart" utility sector [9].

1. "Smart" housing sector, which can conditionally include the following elements that apply smart technologies in the housing sector:

a) the concept of "smart home" (smart house) - "a dwelling equipped with devices, instruments and gadgets interconnected through a communication network, which can be accessed, monitored and controlled from wherever one can enter the Internet. Since most instruments and devices today are available in automated versions, it has become much easier to connect them into a common system and program them to respond to requests from a smartphone, sensor device or computer. Security cameras and locks, room thermostats, lighting, air conditioning systems, multimedia systems, other "smart" devices everything can be connected into one system and controlled remotely" [10]; 
b) the concept of "smart housing" - housing that has certain modern attractive qualities that make it possible to live in it "smartly", for example:

- safe, physically accessible (including for the disabled people), located in the transport accessibility zone, affordable [11];

- economical, environmentally friendly and energy efficient;

- innovative, mobile, created with the use of advanced technologies [12].

In Russia, the concept of "smart housing" is implemented through integration platforms for organizations that manage apartment buildings, whose services have the ability to integrate with the client's website, automatically download information about payments for services made through banks or payment terminals, allow owners of premises in the house to track information about meter readings, make requests to the emergency dispatch service and see how contributions for capital repairs sent to a special account are accumulated and spent [13].

2. "Smart" utilities. The introduction of digital technologies, including the use of the Internet of Things (IoT) in the utilities sector, can solve such problems as:

- strengthening control over the reliability and safety of water, heat, gas, energy supply systems: identifying emergency situations, localizing sources of losses;

- ensuring the efficient use of resources: monitoring consumption, identifying the facts of unauthorized connection and theft, automating the collection and transmission of readings from meters to optimize the calculation of consumption volumes and eliminate errors, control and regulation of the consumption of utility resources;

- formation of charges based on real data on resource consumption, etc. [9]

Thus, the implementation of the ideas of the "smart city" concept at the level of housing and communal services will make it possible to achieve optimal use of resources, increase the energy efficiency of cities, ensure transparency of charges for the use of utilities and implement convenient methods of payment, simplify relations between residents and management companies, etc.

\section{Results}

At the moment, the benefits of digital transformation of the HCS industry are obvious. The use of digital metering devices and platforms that accumulate information about the work of city services, management companies and resource supplying organizations helps to make the process of HCS work and municipal improvement more transparent.

Citizens get the opportunity to really influence the development of the city, get satisfaction from the speed of resolving issues and the absence of bureaucracy. At any time, they can leave a complaint about a violation (an open hatch, left garbage, painted walls, and so on) and track the reaction to it from the MC or the authorities in real time.

"Smart HCS", according to the author, is a set of measures, including a prompt response to emerging utility problems (pipeline breakthrough, power outages, etc.); conducting timely preventive work to avoid possible problems associated with the operation of HCS facilities; or enabling residents to interact directly with city authorities and public utilities through applications and services.

From the author's point of view, in the process of using digital technologies, it is necessary to take into account the following promising areas of digital transformation of the HCS sector (Table 2). 
Table 2. Promising areas of digital transformation of the HCS sector.

\begin{tabular}{|c|c|c|}
\hline Area & Intended use & $\begin{array}{l}\text { Effect of digitalization in the } \\
\text { development of HCS }\end{array}$ \\
\hline $\begin{array}{l}\text { SIS HCS (state } \\
\text { information system of } \\
\text { housing and communal } \\
\text { services) }\end{array}$ & $\begin{array}{l}\text { This is a full-fledged centralized } \\
\text { information resource created to } \\
\text { gain access to information on the } \\
\text { cost of services, accounts payable } \\
\text { and the setting of tariffs for the } \\
\text { next regulatory period, as well as } \\
\text { organizations carrying out } \\
\text { activities in the field of MKD } \\
\text { management. }\end{array}$ & $\begin{array}{l}\text { SIS HCS allows consumers to } \\
\text { monitor the quality and volume of } \\
\text { work performed and services } \\
\text { rendered in real time, monitor the } \\
\text { expenses of their HOA, send } \\
\text { electronic complaints and appeals to } \\
\text { housing supervision authorities, } \\
\text { resource supply organizations, } \\
\text { management companies and HOAs, } \\
\text { and also hold electronic meetings of } \\
\text { house residents in the future. }\end{array}$ \\
\hline $\begin{array}{l}\text { Digital twin of the } \\
\text { housing stock }\end{array}$ & $\begin{array}{l}\text { It is a system of objective } \\
\text { automatic accounting and } \\
\text { forecasting of energy consumption, } \\
\text { quality control of utilities and } \\
\text { forecasting emergency situations. }\end{array}$ & $\begin{array}{l}\text { With the help of the digital twins of } \\
\text { the utility infrastructure, it is } \\
\text { possible to identify accidents and } \\
\text { pre-emergency situations or } \\
\text { infrastructure objects requiring } \\
\text { urgent repair in real time. } \\
\text { Digital twins also allow automatic } \\
\text { control of the supply capacity of } \\
\text { utility resources (flexible supply) } \\
\text { depending on variables } \\
\text { (consumption volume, outdoor } \\
\text { temperature), taking into account } \\
\text { user scenarios based on the analysis } \\
\text { of consumption peaks. }\end{array}$ \\
\hline Digital model of HCS & $\begin{array}{l}\text { This is a platform that allows } \\
\text { collecting up-to-date information } \\
\text { on the state of the industry in the } \\
\text { region on a single resource. The } \\
\text { data can be used by the authorities } \\
\text { responsible for the HCS sector, } \\
\text { including state housing } \\
\text { inspections, regional capital repair } \\
\text { funds, tariff regulation authorities, } \\
\text { etc. }\end{array}$ & $\begin{array}{l}\text { The digital model of HCS allows for } \\
\text { system monitoring of the state of the } \\
\text { industry, and also has the ability to } \\
\text { receive information from the federal } \\
\text { level in its region. In addition, it } \\
\text { contributes to the creation of a } \\
\text { digital ecosystem between } \\
\text { consumers in the HCS sector and the } \\
\text { entire business community, which } \\
\text { supplies goods, works and services } \\
\text { to the industry, as well as to improve } \\
\text { the quality and efficiency of } \\
\text { decisions made by the authorities. }\end{array}$ \\
\hline Billing system & $\begin{array}{l}\text { This is a software package for } \\
\text { supporting the business processes } \\
\text { of enterprises in the housing sector. }\end{array}$ & $\begin{array}{l}\text { Modern billing systems ensure the } \\
\text { growth of the management company } \\
\text { with the ability to launch new tariff } \\
\text { regulations, ensure, among other } \\
\text { things, the speed of settlements and } \\
\text { reduce overall costs. The systems are } \\
\text { able to integrate with other corporate } \\
\text { systems, previously used packages, } \\
\text { and fully automate the conduct of } \\
\text { mutual settlements, guaranteeing a } \\
\text { high degree of transparency and data } \\
\text { protection. }\end{array}$ \\
\hline $\begin{array}{l}\text { Blockchain } \\
\text { technologies in HCS }\end{array}$ & $\begin{array}{l}\text { A database built on complex } \\
\text { mathematical calculations with } \\
\text { cryptographic protection of the }\end{array}$ & $\begin{array}{l}\text { The introduction of blockchain into } \\
\text { the HCS system can, first of all, } \\
\text { solve the problem of non-transparent }\end{array}$ \\
\hline
\end{tabular}




\begin{tabular}{|c|c|c|}
\hline & $\begin{array}{l}\text { transmitted information in the } \\
\text { chain. The peculiarity of } \\
\text { blockchain operation is that data is } \\
\text { stored by tens, sometimes } \\
\text { thousands of people, united via the } \\
\text { Internet into one common group. }\end{array}$ & $\begin{array}{l}\text { settlements with energy suppliers, } \\
\text { i.e. track the flow of funds from the } \\
\text { consumer to the resource-sharing } \\
\text { organization directly without } \\
\text { intermediaries. Blockchain can } \\
\text { provide transparency in the } \\
\text { procurement of resources and their } \\
\text { movement from the resource } \\
\text { supplying organization to the end } \\
\text { consumer. }\end{array}$ \\
\hline $\begin{array}{l}\text { Internet of Things } \\
\text { (IoT) }\end{array}$ & $\begin{array}{l}\text { This is an online system consisting } \\
\text { of recording and measuring } \\
\text { devices that have the ability to self- } \\
\text { identify and acquire "intelligent" } \\
\text { behavior, transmit information } \\
\text { about themselves to other objects, } \\
\text { receiving, in turn, information } \\
\text { about them. Thanks to this, the } \\
\text { management company and each } \\
\text { individual citizen can have the } \\
\text { most complete information about } \\
\text { the condition of the dwelling } \\
\text { (technical characteristics, } \\
\text { information on energy } \\
\text { consumption, information on } \\
\text { expenses and income, etc.). }\end{array}$ & $\begin{array}{l}\text { When using IoT technologies, it } \\
\text { became possible to effectively } \\
\text { remotely control many HCS devices } \\
\text { and objects, for example, control of } \\
\text { lighting, air conditioning, control of } \\
\text { heating devices, etc. In addition, IoT } \\
\text { technologies make it possible to } \\
\text { access statistical information on the } \\
\text { energy consumption of an entire } \\
\text { building or dwelling for any period } \\
\text { of time from any technical device } \\
\text { located anywhere in the world. }\end{array}$ \\
\hline $\begin{array}{l}\text { Dispatching and } \\
\text { automation in the HCS } \\
\text { sector }\end{array}$ & $\begin{array}{l}\text { This is an information system } \\
\text { considered as an integral part of } \\
\text { the entire automation complex and } \\
\text { designed to expand the } \\
\text { functionality of the technical } \\
\text { capabilities of the automation } \\
\text { process. }\end{array}$ & $\begin{array}{l}\text { Dispatching and automation in the } \\
\text { HCS sector increases the efficiency } \\
\text { of energy use. Reduces uncontrolled } \\
\text { consumption of water, gas, heat and } \\
\text { electricity. Significantly reduces the } \\
\text { total costs of maintaining } \\
\text { engineering systems and utility } \\
\text { infrastructure facilities. Carries out } \\
\text { control of emergencies and prompt } \\
\text { response, which means timely } \\
\text { elimination of accidents. All } \\
\text { connected engineering systems are } \\
\text { monitored centrally. }\end{array}$ \\
\hline
\end{tabular}

Source: made by the author

The presented variety of prospects for the development of "smart HCS" in the conditions of digitalization of the urban environment can be realized only when creating a single information environment for control and supervision in the field of housing and communal services, including subsystems:

1) management of HCS, which is responsible for planning and accounting for the implementation of corresponding services;

2) inspection of the housing stock, supervising and controlling over the activities of management organizations;

3) management of citizens' appeals, ensuring the formation and execution of citizens' appeals by management organizations.

Thus, the transition to "smart HCS" will significantly improve interaction between the main participants in the business process, reduce total costs, and minimize the risks that exist in the traditional form of organization and management of communal services. 


\section{Discussion}

At the regional and municipal levels, according to experts, "there are many successfully implemented integrated platform solutions in the field of HCS that implement the requirements of the Smart City standard, including certification and control of the life cycle of housing facilities, accounting for resource consumption and monitoring the state of infrastructure facilities, automation and control activities of management companies for housing stock management, centralization of dispatching functions, automation of capital repairs management, centralization of functions for calculating payments and working with consumers, etc." [7].

For "smart HCS", a system of key indicators was proposed, approved by the order of the Ministry of Construction, Housing and Utilities of the Russian Federation, which determine the level of active implementation and use of smart technologies in this industry: the presence of a smart metering system and, accordingly, the proportion of apartment buildings equipped with this resource consumption metering system; the presence of a system for monitoring the condition of buildings and, accordingly, the proportion of apartment buildings using this system; holding general meetings of residents through electronic voting.

Nowadays, the state and level of digital HCS in an apartment building is determined through the indicator of the use of "smart" metering devices for the consumption of utility resources. So, as for 2019, 1.4 million apartment buildings, 18.9 million residential buildings, 618 thousand management companies, and 51 thousand homeowners' associations were registered in the SIS HCS. This is the target audience for which digital solutions and products are developed.

The analysis of the smart HCS market showed that "the overall level of equipping with metering devices in Russia is still low. For example, less than $30 \%$ of apartment buildings have common household metering devices. There are still different opinions about who should pay for the installation of such devices. The level of equipping with individual metering devices varies from $50 \%$ for water supply to $80 \%$ for power supply. And the share of metering devices capable of transmitting data remotely in the residential sector is negligible - less than 1\%" [14].

Table 3 shows data on the level of equipping the apartment buildings with metering devices for the consumption of utility resources.

Table 3. The level of equipping the apartment buildings with metering devices.

\begin{tabular}{|l|c|c|c|c|c|c|}
\hline \multicolumn{1}{|c|}{ Indicator } & $\begin{array}{c}\text { Cold } \\
\text { water } \\
\text { supply }\end{array}$ & $\begin{array}{c}\text { Hot water } \\
\text { supply }\end{array}$ & $\begin{array}{c}\text { Electric } \\
\text { energy }\end{array}$ & Gas & $\begin{array}{c}\text { Thermal } \\
\text { energy }\end{array}$ & $\begin{array}{c}\text { Domestic } \\
\text { waste water }\end{array}$ \\
\hline $\begin{array}{l}\text { 1. Number of } \\
\text { apartment } \\
\text { buildings to } \\
\text { which the } \\
\text { resource is } \\
\text { supplied }\end{array}$ & 867000 & 487000 & 1179000 & 711000 & 631000 & 734000 \\
\hline $\begin{array}{l}2 . \% \text { of apartment } \\
\text { buildings } \\
\text { equipped with } \\
\text { general metering } \\
\text { devices }\end{array}$ & $28 \%$ & $24 \%$ & $34 \%$ & $0.4 \%$ & $33 \%$ & $0.4 \%$ \\
\hline $\begin{array}{l}3 . \text { Number of } \\
\text { apartment } \\
\text { building premises } \\
\text { to which the }\end{array}$ & 51835 & 38571 & 63540 & 38941 & 42945 & 46710000 \\
\hline
\end{tabular}




\begin{tabular}{|l|l|l|l|l|l|l|}
\hline $\begin{array}{l}\text { resource is } \\
\text { supplied }\end{array}$ & & & & & & \\
\hline $\begin{array}{l}4 . \% \text { of equipping } \\
\text { apartment } \\
\text { building premises } \\
\text { with metering } \\
\text { devices }\end{array}$ & $52.7 \%$ & $48.5 \%$ & $80 \%$ & $44 \%$ & $3 \%$ & $2 \%$ \\
\hline
\end{tabular}

Source: [14]

However, it should be noted that the potential for the development of digital housing and communal services is influenced by a number of problems that exist today, and the further implementation of the "smart city" project depends on their prompt solution. So, experts note the absence of a unified data system in which there is no description of data objects and connections between them, reference data sources for objects are not highlighted, and the model of information flows is not defined (who, to whom, what information under what conditions is transmitted, etc.). This fact negatively affects the possibility of applying successful regional industry digital solutions and the effectiveness of intra-industry interaction. The situation is similar with data on owners, taking into account residential real estate and their parameters (area, number of rooms, etc.). Therefore, one of the key functions of digital HCS should be the end-to-end integration of economic entities according to data based on a unified data system [15].

In addition, the existing regulatory framework for the regulation of housing and communal services in the field of digitalization is almost completely absent, which does not allow its participants to significantly influence the further development of digital technologies in relation to housing and communal services. Another problematic issue of improving digital housing and communal services is the lack of a mechanism for attracting investment in this area.

To solve existing problems, it is necessary to systematize the processes of the life cycle of the development of information systems in the field of HCS, create tools for aggregating information, as well as coordinate projects around a single legal field.

\section{Conclusions}

Summing up the results of the study, it should be emphasized that today, utilities provided by management companies, thanks to the introduction and use of smart technologies, are becoming more transparent and understandable to the population. Digital platforms make it possible to involve citizens in the assessment and management of residential real estate, which is becoming the main driving force behind the development of digital housing and communal services. As a result of the presented digital transformations of the HCS sector, the "smart city" will become attractive for life, capable of using the territorial and resource potential available to it as efficiently as possible.

Thus, the active implementation of the concept of "smart HCS" will help in solving such problems as:

- to focus the state's attention on the need for active digitalization of the HCS sector, which will increase the readiness of management companies and resource supplying organizations to use digital technologies for high-quality provision of communal services to the population;

- to intensify work on the formation of a unified information environment for control and supervision in the field of HCS through the further development of SIS HCS;

- to improve intelligent systems in order to support decision-making in crisis and emergency situations, providing information and cyber security of HCS. 


\section{References}

1. Order of the Ministry of Construction of the Russian Federation of 31.10.2018 No. $695 / \mathrm{pr}$ "On approval of the passport of the departmental project of Digitalization of urban economy "Smart City" (2018). - URL http://www.minstroyrf.ru/upload/iblock/ecf/Pasport-proekta-umnyy-gorod.pdf (24.01.2021).

2. Guidelines for the preparation of the regional project "Smart city" programs, the development of digital economy of the Russian Federation from 15.11.2018 (2018). - URL: https://minstroyrf.gov.ru/docs/17596/ (30.01.2021).

3. The use of Internet of Things technologies for the development of a modern urban environment (2018). - URL: https://www.pwc.ru/ru/iot/iot-for-cities.pdf (24.01.2021).

4. M. Tolstov, Step to a smart city: how housing and communal services are digitalized in Russia (2020). - URL: https://rb.ru/opinion/shag-k-umnomu-gorodu/ (24.01.2021).

5. Decree of the Government of the Russian Federation No. 1632 of 28.07.2017 - On the Approval of the program "Digital Economy of the Russian Federation" (with amendments and additions) (2017) [Electronic resource]. - URL: http:/ http://base.garant.ru/71734878/ (23.01.2021).

6. Smart HCS (2019) - URL: https://iot.ru/wiki/umnoe-zhkkh (30.01.2021).

7. A.I. Kulishov, Digitalization of housing and communal services as a strategic planning of its development, Metod J. 3, 10-13 (2019).

8. Information technologies for HCS and SHA (2020). - URL: http://youhouse.ru/spec_po/4.php (31.01.2021).

9. Smart City - smart HCS: an overview of the trends of digitalization of urban (2019)

URL: http://www.urbaneconomics.ru/sites/default/files/umnyy_gorod_avgust_2019_2_0 .pdf (31.01.2021).

10. Smart Houses: The Future of Sustainable Housing (2019). - URL: https://www.ictlt.com/smart-houses-the-future-of-sustainable-housing (06.02.2021).

11. Neighborhood Housing and Community Development, S.M.A.R.T. Housing Policy. Resource Guide (2018). - URL:

https://www.austintexas.gov/sites/default/files/files/Housing/Application_Center/S MART_Housing/smart_guide_0708.pdf (06.02.21).

12. Latest Results from Smart Housing Project at Clarkson University (2017). - URL: https://www.youtube.com/watch?v=M6ToqyqRio8 (06.02.21).

13. K. Arsenieva, Smart home management: Internet at the service of HCS (2020). URL: http://youhouse.ru/news/?id=242 (07.02.21).

14. N. Noskov, HCS as an arena for the introduction of the Internet of Things, IKS J., 3 (2020). - URL: https://www.iksmedia.ru/articles/5669547-ZhKX-kak-arenavnedreniya-interneta.html (14.02.21).

15. K. Potapova, The key to city management, KOMMERSANT BUSINESS GUIDE J., 208, 21-22 (2019).

16. A. Dan, A.C. Sánchez, The Evolution of Homeownership Rates in Selected OECD Countries: Demographic and Public Pol-icy Influences, OECD J., 1, 11-37 (2011).

17. UTILITY 2.0: Winning over the next generation of utility customers (2017). URL: $\quad$ https://www2.deloitte.com/us/en/pages/energy-andresources/articles/digital-transformation-utilities-customers.html (13.02.2021). 
18. Digitalization of utilities operations triggering value creation (2019). - URL: https://www.altran.com/as-content/uploads/sites/12/2019/04/digitalization-ofutilities-operations_web.pdf (13.02.2021).

19. Digital transformation: focus on the utilities industry (2020). - URL: https://www.i-scoop.eu/digital-transformation/digital-transformation-focus-on-theutilities-industry/ (14.02.2021).

20. Digital Transformation in Energy and Utility Companies (2019). - URL: https://www.ibm.com/downloads/cas/WRK68YGB (14.02.2021).

21. The Digital Utility (2017). - URL: https://www.avanade.com/-/media/asset/pointof-view/the-digital-utility-pov.pdf (14.02.2021).

22. Digital utility transformation (2015). - URL: https://www.pwc.com/gx/en/utilities/publications/assets/pwc-digital-utilitytransformation.pdf (14.02.2021). 